\title{
World Wild Web: Funding connectivity conservation under climate change
}

\begin{abstract}
Ralf Buckley
Abstract. Connectivity is one key to conservation under anthropogenic climate change. Shortfalls in financial and political support are more critical constraints than deficiencies in biological data. This applies especially for private lands in developed nations and public lands in developing nations. Here I examine 3 funding mechanisms: tourism, stewardship schemes, and global branding

A small number of commercial tourism operations make positive net contributions to conservation, some of global significance. Their models deserve duplication. Stewardship schemes have been politically motivated and ecologically ineffective, but they mobilise considerable funds. Principles for effective design are proposed. A well-branded worldwide initiative to link connectivity conservation efforts across national and continental borders could tap new large-scale multilateral funding for adaptation to climate change

In addition, a worldwide initiative could improve links between the many different current mechanisms for connectivity conservation. For example, bilateral aid projects could kickstart conservation tourism in severely impoverished nations. Proximity to protected areas outside national borders could become a criterion for national stewardship incentives. If other potential mechanisms such as water sales or carbon offsets do prove to generate significant conservation funding, they can also be incorporated into the World Wild Web.
\end{abstract}

\section{INTRODUCTION}

Connectivity conservation (Beier and Noss 1998; Sutherland 2000; Salafsky et al. 2002; Crooks and Sanjayan 2006; Rouget et al. 2006) arose as one response to the isolation and fragmentation of conservation reserves in increasingly modified and fragmented landscapes (Millenium Ecosystem Assessment 2005; Wiegand et al. 2005; Fischer and Lindenmayer 2007; Pressey 2007). It also provides one possible response to the biological impacts of anthropogenic climate change (Pressey et al. 2007). It is endorsed by conservation groups and government agencies (Bennett 1999; Pressey 2007; Conservation International 2008; IUCN 2008; The Nature Conservancy 2008; Worldwide Fund for Nature 2008).

Connectivity conservation includes continent-wide initiatives such as the Wildlands Project (2008) in North America, the PANParks initiative in Europe, the Alps-to-Atherton initiative in Australia (NSW DECC 2008), and unbranded efforts by private corporations such as Conservation Corporation Africa (2008) and Wilderness Safaris (2008) in sub-Saharan Africa. Some countries have also incorporated some of their public parks into transboundary protected areas.

Significant research effort has been devoted to the ecological design of connectivity conservation programs, with emphasis on hotspots (Myers et al. 2000; Brooks et al. 2006); coldspots (Kareiva and Marvier 2003; Leroux and Schmiegelow 2007); and corridors (Beier and Noss 1998; Bennett 1999; Sutherland 2000; Damschen et al. 2006; Rouget et al. 2006; Shepherd and Whittington 2006; Wilson et al. 2007; Lees and Peres 2008). Relevant information is no doubt far from complete. There are, however, many areas which have been identified as highly significant for biodiversity conservation, but remain unprotected. Lack of political and financial support is thus a more critical constraint than deficiencies in biological data.

Existing public protected areas worldwide are under pressure for increased human use, whether for outdoor recreation, subsistence harvesting, mineral exploration, or resumption for primary industries. In addition, many sites key for biodiversity conservation lie outside protected areas, in regions with relatively dense human populations (Rondinini et al. 2006). It is politically improbable that connectivity under climate change can be achieved by dedicating further public protected areas, either in developing or developed nations. Therefore, mechanisms to promote conservation management of other public and private land tenures are critical. Funding is a necessary component of all such mechanisms, though there are also political, legal and management aspects. Here, therefore, I examine mechanisms to fund off-reserve conservation as a key component of global connectivity conservation, itself a key response to anthropogenic climate change.

Conservation funding mechanisms in general were reviewed for the Fifth World Parks Congress by the Conservation Finance Alliance (2003). In addition to government budget appropriations which form the principal funding source for protected area management agencies in developed nations, they listed 11 other sources: bilateral and multilateral donors, biodiversity enterprise funds, bio-prospecting, carbon offset projects, debt swaps, environmental funds, fiscal instruments, foundations, watershed services payments, resource extraction fees and tourism-based fees.

Some of the specific applications of the measures listed by the Conservation Finance Alliance (2003) have been ineffective or even detrimental to conservation (Terborgh 1999; Iverson et al. 2006; Shone and Caviglia-Harris 2006; Wunder et al. 2008). Similarly, many conservation stewardship schemes seem to have been politically motivated subsidies to rural electorates, with little conservation benefit (Kleijn and Sutherland 2003). Donors, funds, foundations and various fiscal instruments have remained important sources of conservation funding. Debt swaps, bioprospecting and watershed service fees have not yet lived up to their initial promise, but may yet do so in modified form. Watershed service fees seem to have been pursued particularly in Latin America (Asquith et al. 2008;
Authors' AdDress: Ralf Buckley, International Centre for Ecotourism Research, Griffith University, Gold Coast 4222, Australia.

r.buckley@griffith. edu.au

Tel +61.7.55528675

Fax +61.7.55528895 
Kosoy et al. 2007; Munoz-Pina et al. 2008; Pagiola 2008). Carbon offsets have been used widely to promote plantations, but are still in their early stages as a practical conservation mechanism to fund connectivity conservation. Resource extraction in protected areas is highly politicised in most countries. Parks agencies may be permitted to charge fees for small-scale harvesting and beekeeping, for example, but not for large-scale mineral or petroleum exploitation.

Opportunities to generate funding for off-reserve conservation may also be applicable, in less wealthy nations, to support public protected areas which are at risk of resumption to subsistence agriculture or commercial logging (Terborgh 1999; Wilkie et al. 2006). In general, different packages of measures and incentives are needed to promote the conservation of biodiversity within existing protected areas, on other public lands, and on private landholdings (Langholz et al. 2000; Ferraro and Kiss 2002).

In this paper I focus on three possible mechanisms to improve funding for global connectivity conservation: tourism, stewardship schemes and global branding. Tourism-based fees were mentioned by the Conservation Finance Alliance (2003) in relation to public protected areas. Here, I review some examples of commercial tourism operations which make significant positive net contributions to connectivity conservation by funding private reserves and community conservancies. Stewardship incentive schemes were not listed by the Conservation Finance Alliance (2003) but have been adopted by a number of countries to encourage conservation management of private lands. I consider here how stewardship incentive schemes could be designed so as to make a more effective contribution to global connectivity conservation. Finally, I put forward a proposal for a globally branded connectivity conservation initiative under the tentative title of the World Wild Web, and consider how it might attract large-scale multilateral funding and national political support.

\section{POLITICAL, LEGAL AND MANAGEMENT CONTEXT}

Funding is a necessary prerequisite for almost all connectivity conservation programs, but it is not sufficient alone (Johns 2007). Such programs also need political support, an effective legal basis, and practical management skills. In addition, different countries, regions, organisations and landholders commonly have very different social, environmental, economic and political circumstances. Most measures intended to improve conservation management of land at local scale have arisen independently, with similar goals but different mechanisms. Attempts to globalise such measures must take account of local circumstances (Terborgh 1999; Sutherland 2000; Abakerli 2001; Wilkie et al. 2006). Different approaches are needed in different places in order to muster political support, establish a legal basis for conservation management, and provide practical conservation management on the ground.

Without political support, protected areas may be abolished completely, as occurred for some former national parks in Zimbabwe. They may lose effective protection to become paper parks, widespread in many parts of the world. They may be reduced in size, as for the Etosha Pan protected area in Botswana, or a former World Heritage oryx reserve in Oman. They may suffer attrition or delays in receiving their operating budgets, leading to temporary closure as occurred some years ago in the USA. They may suffer excisions or fragmentation, and consequent loss of conservation value, for uses such as mineral production, oil and gas, powerline corridors, roads or tourist developments.

These problems apply in both developed and developing nations. Parks agencies in developed nations have to run marketing campaigns to remind people of their value (Watson and Borrie 2003). Governments budget for conservation incentive schemes only where this has broad political support. Landowners who establish game reserves and tourist lodges need support from their neighbours to prevent poaching. Communities need consensus in order to lease jointly-owned land for wildlife tourism and conservation. These are all essentially political issues.

There are three key legal aspects to connectivity conservation: parks legislation, land tenure and tax law. Parks legislation defines, for example: what rights parks agencies have to control resources within protected areas; what options they have to raise funds to buy new protected areas; what restrictions they can apply to activities that affect endangered species outside protected areas; and what authority they have to enter into agreements with neighbouring landholders.

Different types of private or community land tenure comprise bundles of rights in different countries. Investors who purchase land zoned for development, for agriculture, or for forestry may be compelled by law to pursue that designated land use, with no option to manage the land for conservation. In some countries, private landholders can own native wildlife; in some they cannot; in some they can own only certain species. Indigenous peoples and local communities have land rights in some nations, but the arrangements differ considerably. Such communities may or may not have the right to prevent other people moving in and diluting the benefits they can obtain from their land. They may have rights of use but no formal title, so that even if they grant a tourism company permission to operate, the company will not have a title to provide security for loans to finance construction of facilities.

Taxation treatment of conservation land use and investment is critical for private landholders and foundations. In the USA, for example, land trusts effectively allow wealthy individuals to offset conservation management costs against other income. In Australia, in contrast, whilst there is a weak provision for tax deductibility of capital losses if land is brought under a conservation easement, ongoing operational costs of conservation management cannot be offset against other sources of income. Private conservation management is therefore much less common in Australia than the USA.

Conservation management on the ground needs skilled personnel (Lockwood et al. 2006). Where land is added to the 
public protected area estate, parks agencies have necessary management skills, though not necessarily resources. Where private landholders convert farmland to conservation, the new land use needs new skills. Restoring a landscape from introduced pasture grasses suitable for cattle, to a mixture of native woody and herbaceous plants suitable for native wildlife with very different food preferences, can be a difficult, long-term and expensive exercise. Managing small populations of many different wildlife species simultaneously is very different from managing a single herd of cattle, sheep or goats. Capture, translocation and reintroduction of animal species is a highly skilled profession, particularly for species which are large, potentially dangerous and/or endangered. Where tourism is used to generate income for conservation, another and equally specialised set of skills is needed in order to run successful commercial tourism operations. Few organisations or individuals combine all these skills simultaneously.

Acknowledging that all sources of funding for connectivity conservation have political, legal and management aspects as above, I now examine the three specific funding mechanisms outlined earlier.

\section{TOURISM FUNDING CONSERVATION}

Private conservation reserves and community conservancies funded by tourism are becoming increasingly commonplace worldwide (Buckley 2003, 2008; Kruger 2005; Puppim de Oliveira 2005; Shultis and Way 2006; UNEP 2007). The best-known and earliest examples are in southern Africa, particularly in Botswana, Namibia and South Africa itself. Companies such as Conservation Corporation Africa (2008) and Wilderness Safaris (2008) have developed successful business models which rely on wildlife tourism to fund quite large-scale conservation efforts, including habitat restoration, anti-poaching efforts and wildlife relocation programmes (author, pers. obs. 2001-2008). Wilderness Safaris (2008), for example, has brought over a million hectares of land in Botswana and Namibia, principally community land, into conservation use. Conservation Corporation Africa (2008) has successfully established a considerable number of private conservation reserves funded through tourism, largely in South Africa, and has pioneered restoration, restocking and wildlife relocation techniques.

Tourism, for example, funds the private reserves of the Sabi Sands area, which has effectively added 65000 ha to Kruger National Park in South Africa (Buckley 2003), and the Madikwe private reserve adjacent to the Botswana border (Buckley 2008). There are many individual operators in each, including Conservation Corporation Africa. In Madikwe, the individual landowners have removed internal fences and operate the entire area as a single co-managed reserve. In Sabi Sands, they have not only removed fences between private reserves, but also between these and the public national park. Conservation Corporation also established the Phinda private reserve which extends the St Lucia World Heritage Area in south-eastern South Africa, and the Kwandwe reserve which provides critical habitat for the Endangered Blue Crane in the southwest. In addition, it pioneered capture, translocation and "soft release" techniques for the active population management of a number of endangered wildlife species.

Similar approaches have been followed by Wilderness Safaris. Its Ongava private reserve, adjacent to Etosha Pan national park in northern Namibia, effectively extends the area of the public park and is separated from it by a "semi-permeable" fence which allows some animal species through, whilst retaining others. A series of adjacent community conservancy areas leased by Wilderness Safaris and funded by tourism is gradually building a conservation corridor between the Etosha Pan ecosystems of northeastern Namibia and the arid ecosystems of the Skeleton Coast in the northwest, habitat for desert-adapted elephants. This corridor runs adjacent to the border with Angola, and once politics allow, cross-border connectivity will also be feasible. South of the Skeleton Coast, Wilderness Safaris leases a community conservancy which supports the largest remaining population of desertadapted rhinoceros. It also supports extensive research on rhino populations, ecology and conservation, both directly and through an NGO, the Save the Rhino Trust (2008). In Botswana, it funded the reintroduction of rhino, previously poached to local extinction, into the publicly owned Moremi reserve in the Okavango Delta, and leases large areas which it runs for conservation funded by tourism.

A large number of smaller companies have adopted similar models, though with fewer sites and smaller areas. Similar tourism-based models, often run by the same companies, also help to fund conservation in public conservation reserves and conservancies in east Africa and elsewhere. Conservation Corporation Africa (2008), for example, operates a series of private reserves in east Africa, leased from the national governments and converted from subsistence agriculture and hunting to wildlife conservation (Buckley 2006). These effectively extend the protected area of the Serengeti ecosystem. It has established a marine reserve at Mnemba Island off the coast of Zanzibar (Buckley 2006), similar to the private marine reserve at Chumbe Island (Buckley 2003). Through a joint venture known as Taj Safaris, Conservation Corporation Africa has recently built 4 tourist lodges to support tiger conservation in India. It is currently providing technical expertise to relocate Gaur, the Endangered Indian Wild Ox, as part of a continent-wide conservation program.

There are also private reserves funded by tourism, though generally at a smaller scale, in various countries in the Americas, Asia, Europe and Australasia (Buckley 2003, 2008; Conservation Finance Alliance 2003; Lindsey et al. 2005; Svoronou and Holden 2005; Tisdell et al. 2005). Tourism is not always the sole source of income for these reserves. Some receive support from bilateral or multilateral aid. Some were established and operated by philanthropic individuals or conservation organisations such as Conservation International (2008), The Nature Conservancy (2008), the Worldwide Fund for Nature (2008) or the Australian Wildlife Conservancy 
(2008). There are examples of private reserves with NGO involvement and ecotourism operations in, e.g.: Australia, Belize, Brazil, Chile, China, Ghana, Greece, Indonesia, Mexico, Namibia, Nepal, Panama, the Phillippines, the Seychelles, South Africa, the United Arab Emirates and Zambia (Buckley 2008, table 7.2). There are also public reserves which have been established with the assistance of particular tour operators, such as the Khutzeymateen grizzlybear sanctuary in Canada (Buckley 2008). Both Conservation International (2008) and the Worldwide Fund for Nature (2008) now advertise a global suite of tours through their own websites, as one way to generate political and financial support. They use particular commercial tour operators with good environmental credentials, such as Natural Habitat Adventures (2008) to provide those tours (Worldwide Fund for Nature 2008).

There are many other countries, including other African nations, where similar tourism-funded conservation models have operated in the past and/or could operate in the future, but where political circumstances prevent them operating effectively at present. Tourism-funded conservation models cannot function well in countries where war or terrorism threaten the safety of tour clients; where basic infrastructure such as roads and airports are too run-down; or where land tenure is too unstable for a private tourism operator to invest. If and when such countries adopt or return to relatively stable democratic systems of government, they will probably be able to call on significant international aid funding to help rebuild infrastructure, perhaps including parks infrastructure. Such aid programmes are typically short-lived, however, and a longer-term source of income is needed once aid funding comes to an end. The opportunity for tourism to take over conservation funding in nations such as these is thus particularly significant, since companies already operating in the region have established clienteles who would visit new destinations.

At a global scale, therefore, tourism has become a significant source of funding for connectivity conservation, though currently much more prevalent in particular regions and restricted to a relatively small set of tourism operators. The tourism industry more broadly does not necessarily contribute to conservation, and indeed generates a wide range of ecological impacts; but if an adequate conservation framework is in place, tourism can generate significant funding to support it. Indeed, for a small number of leading ecotour operators whose owners are driven by conservation concerns, they may also help to establish such conservation frameworks, by providing examples of what can be achieved. There are thus an increasing number of connectivity conservation initiatives, particularly in developing nations, where private tourism operations play a key role. To date, however, there are rather few where these have been linked across national borders.

\section{CONSERVATION INCENTIVE SCHEMES}

Conservation stewardship and incentive payments, or tax concessions, for individuals to carry out conservation on private landholdings are now widespread in developed countries. They form a logical component of connectivity conservation where five conditions are met. (1) Significant areas of land with high conservation value are in private ownership. (2) The market value of land is too high for governments to purchase it to add to the public protected area estate. (3) There is adequate information to identify which areas are most valuable for conservation. (4) There are adequate legal mechanisms to formalise conservation management requirements on the land concerned, e.g. through some form of covenant on the land title or some form of agreement with the owner. (5) The government concerned has adequate funds to pay for incentives which are large enough to persuade land owners to convert to conservation management.

Different countries have widely different schemes. They are particularly prevalent in Europe, including the UK and Scandinavia (Knop et al. 2006; Herzon and Mikk 2007; Berentsen et al. 2007; Cooper and Signorello 2008; Dobbs and Pretty 2008; Zabel and Holm-Muller 2008). They are also widespread in North America (Langpap 2006; Rissman et al. 2007; Straka et al. 2007; Claassen et al. 2008; Wallace et al. 2008). There are significant structural differences between European and American programs (Donald and Evans 2006; Murdoch et al. 2007; Baylis et al. 2008). A variety of incentive programs operate in Latin America (Sierra and Rusman 2006; Wunder 2007; Pagiola et al. 2007; Sanchez-Azofeifa et al 2007; Asquith et al. 2008) and in Australia and New Zealand (Cowell and Williams 2006; House et al. 2008; Walker et al. 2008). Stewardship incentive approaches currently have more limited application in Asia (Spiteri and Nepal 2006; Engel and Palmer 2008) and Africa (Gardner et al. 2007; Turpie et al. 2008). There has been extensive modelling of different approaches (e.g. Holzkamper and Seppelt 2007; Engel et al. 2008). Connectivity is a landscape-scale endeavour, so stewardship incentive schemes need explicit spatial targeting in order to be most effective (Drechsler et al. 2007; Goldman et al. 2007; McDonald et al. 2007; Parkhurst and Shogren 2007; van der Horst 2007; Wunscher et al. 2008).

Much of the land affected is zoned for agriculture. Historical subsidies and tax concessions for land clearance, drainage or drought relief have caused land degradation rather than conservation. Kleijn and Sutherland (2003) found that few European agri-environment schemes had made significant conservation contributions, and most were disguised subsidies. Some schemes reward landholders simply for ceasing to breach laws which require them to remove noxious weeds, prevent pollution of surface waters, protect endangered species, or maintain stocking rates below predefined thresholds. Some pay them for measures aimed mainly to increase agricultural production, such as: planting windbreaks, shade trees, hedgerows or woodlots; establishing dams to impound surface runoff; or controlling weeds, erosion and livestock.

If conservation incentive schemes are to be used effectively, they should reward only conservation management beyond basic legal and agricultural requirements. Management measures 
specifically for conservation may include: retaining undisturbed native vegetation; fencing livestock out of watercourses and wetlands; maintaining mature trees as seed sources or as breeding sites for native bird or mammal species; maintaining mixed-species meadows to conserve particular plant species; maintaining warren or burrow areas, or areas of rock or dense vegetation to provide refuges for small mammals; retaining a continuous vegetation canopy across roads and tracks to allow arboreal mammals to cross without descending to the ground; and controlling feral and domestic dogs, cats and other predators. Expertise in conservation biology, for the particular species concerned, is generally needed to determine ecological goals and the management practices required to achieve them (Murphy and Noon 2007).

Once the ecological goals are determined, a variety of different financial and legal mechanisms are available (Gulati and Verkammen 2006; Hallwood 2007; de Nooij et al. 2008; Ferraro 2008). These include, e.g.: tax concessions for capital losses and/or ongoing operational costs; direct grants or subsidies calculated according to predefined rules for particular conservation actions; negotiated payments for conservation easements on large and significant areas of land; tender systems where different land owners can bid competing amounts as the price of adopting conservation management practices; and a variety of hybrid schemes. Different approaches are more effective under different socioeconomic circumstances. Landowners making a loss from agricultural production are little influenced by tax concessions, whereas those with other income sources find them persuasive. Discretionary grant systems with high information and transaction costs are unlikely to achieve high take-up if landowners must invest significant time in preparing applications with low success rates. Sufficiently widespread and well funded schemes, however, create markets for conservation brokers who lodge bids on a fee-for-service basis, as in the USA.

From a practical conservation policy perspective, I propose five general principles for the structure of conservation incentive schemes, irrespective of detailed design. (1) Conservation is cheaper than restoration, so focus on protecting areas of high conservation value, and only occasionally on restoring areas already degraded. (2) There is rarely sufficient funding, so focus on areas of highest conservation value. (3) Different areas have different conservation values and management approaches, so design multiple tiers to reflect these differences. (4) For effective conservation, use conservation biologists to design the ecological goals. (5) For high take-up, use landholders to design the practicalities of implementation.

The key to funding connectivity conservation through national stewardship schemes, therefore, is to ensure that incentive programs do in fact contribute to conservation and are not merely disguised agricultural subsidies. This requires external scrutiny. It is for this reason that the critical review by Kleijn and Sutherland (2003) generated a strong reaction from individual national governments operating their own agri-environment programs in Europe. In addition, each of these schemes operates entirely within the borders of the nations which fund them. There are no known schemes where proximity to protected areas, public or private, in an adjacent nation has been adopted as a criterion for funding. Indeed, in many large federated nations, schemes are run by subsidiary governments and rarely consider linkages even across subnational borders.

\section{WORLDWIDE CONNECTIVITY AND BRANDING}

A well-branded worldwide initiative to link connectivity conservation efforts across national and continental borders could generate several benefits for connectivity conservation. It could help to link the efforts of conservation tourism operations and NGO's across national borders, apply successful models to new countries, and link these models to other sources of funding such as international aid. For example, bilateral aid projects could kickstart conservation tourism in severely impoverished nations. Proximity to protected areas outside national borders could become a criterion for national stewardship incentives. A worldwide initiative could bring international scrutiny to bear on conservation stewardship programs funded by individual governments, so as to improve their conservation outcomes. It could provide international support for local conservation programs and NGOs in individual nations, developed as well as developing. This may be of particular significance in large nations with rapid economic growth, as outlined below. It could also generate significant new support directly, by tapping into large-scale multilateral funding for adaptation to climate change.

The goal of major multilateral conservation organisations such as IUCN is indeed to create a global system of conservation reserves adequate to protect biological diversity across the entire planet. To date, the principal approach has been to expand the public protected area networks in as many individual nations as possible. This approach has met with some notable success, and naturally needs to continue. My proposal here is simply that supplementary approaches which have already been used in some countries and continents to extend conservation efforts to other public, private and community lands, could now be applied deliberately at a global scale as a key component of connectivity conservation efforts. A global-scale endeavour may be able to attract global-scale funding more easily than local and national-scale programmes. Connectivity is an increasingly urgent issue both because of climate change and because of continuing clearance of areas outside formal reserves. Connectivity conservation within individual nations and regions may gain political support through a globally recognised, endorsed and visible programme.

For illustration, I have proposed here a name such as World Wild Web or perhaps Wild World, but these are options only. The key is to identify a name which has the greatest appeal, when translated to as many languages as possible, to national governments and multilateral agencies who would need to endorse and support it for it to be successful. If it can also appeal to major private-sector sponsors, that would 
be an additional advantage. The name World Wild Web, for example, is not only descriptive of the intention, but might also appeal to some very well cashed-up internet corporations concerned to demonstrate corporate social responsibility. An extremely miniscule proportional royalty on online financial transactions, for example, could generate very major funding at global scale. This approach has already been trialled with credit cards. If other potential mechanisms such as water sales or carbon offsets do prove to generate significant conservation funding, they can also be incorporated into the World Wild Web. Indeed, there are already programs which use tourism industry funds to buy carbon offsets in order to promote biodiversity conservation (Tourism Industry Carbon Offset Scheme 2008).

One particular conservation concern at present is the very rapid economic growth in the large newly-industrialised nations such as India, Brazil and China. These countries have their own well-established administrative systems, their own cultural histories, their own government priorities, and their own political perspectives and pressures as they seek to provide increasing standards of material wealth for increasing populations. These nations will not necessarily pay much heed to concerns over conservation, if those concerns are raised purely from a Western cultural or scientific perspective. They are, however, very aware that they are in the global spotlight, and they are concerned to bolster their international images as powerful players in global politics. A programme such as that proposed here, with a global name such as World Wild Web, might boost the efforts of domestic conservation interests in each of those nations. This could be particularly significant, for example, in the case of transboundary reserves which overlap from these nations into smaller neighbouring countries, such as the Terai area along the border between India and Nepal.

Global political responses to anthropogenic climate change remain highly contested, but carbon taxes and trading schemes of various types seem likely to generate a significant pool of multilateral funding. In addition, since climate change is rightly seen as a major threat to the world economy, political stability and social development, as well as to the natural environment, it seems highly likely that large-scale multilateral funds will be established to assist in adaptation - mitigation measures are likely to be partially successful at best. There will be a period when such funds, once established, are uncertain where best to direct their spending. Since climate change threatens biodiversity at a global scale, a global connectivity conservation initiative could well attract large-scale support.

Protected areas, both public and private, may also obtain funding directly and individually from carbon offset programs, particularly since recent research by Mackey et al. (2008) has shown that an intact and undisturbed primary forest ecosystem stores an order of magnitude more carbon than previously believed. Many large corporations worldwide are already purchasing carbon offsets from private landowners who have established tree plantations. If parks agencies were paid for the carbon they keep out of the atmosphere, this could provide a significant source of conservation funding. Such approaches do not need to wait for a global-scale initiative such as proposed here. A World Wild Web initiative, however, could help to supplement funding for areas which are important for biodiversity conservation, are affected by climate change, but contribute little to carbon sequestration because they are in arid, saline or cold-climate areas.

The development of a World Wild Web would be a major multilateral exercise, and would require a well-respected multilateral agency such as the IUCN to champion. It would need support from major international conservation organisations and from relevant UN agencies, and national governments prepared to back the initiative in multilateral fora. All of these are entirely possible.

\section{CONCLUSIONS}

Connectivity approaches are an increasingly important component of biodiversity conservation worldwide, firstly because of increasing population growth and associated threats to existing areas of undisturbed habitat, and secondly because of the impacts of anthropogenic climate change. The ecological aspects of connectivity conservation have been subject to considerable research, and while there are doubtless still deficiencies in relevant data, there are practical recommendations for areas which merit urgent protection. The most critical obstacle is not ecological information, but political and financial support.

Tourism has numerous risks and shortcomings as a source of conservation funding, but there are now a number of examples where private tourism corporations have indeed made net positive contributions to conservation, and are indeed focussing their future strategies on connectivity. They could do more if their efforts were linked to other sources of conservation funding, notably international donor and foundation funds in the least developed nations. Opportunities to fund conservation through nature-based tourism are particularly valuable in countries which are politically stable and democratically governed, but not yet very wealthy or highly developed in international terms. In these nations, tourism is often a significant component of national income, and conservation can be promoted as an asset to support tourism.

Stewardship and incentive programs, nominally established specifically to promote conservation and enhance connectivity, have largely been ineffective because they have been operated as disguised subsidies for political ends. They can indeed make significant contributions to connectivity conservation, especially in developed nations, but only if they are redesigned and operated under much closer scrutiny. In addition, to maximise connectivity gains, systems operating in individual countries also need to consider conservation patterns in neighbouring nations. Whilst there are differences in legal structures and land tenure systems between countries, there are also overarching principles which could be applied 
quite broadly. In addition, if the wealthier nations decide to fund conservation incentive schemes in more impoverished countries, they will need to reach multilateral agreement on the design of such programmes.

Opportunities to harness these and other sources of funding and support for connectivity conservation could be enhanced by the establishment of a globally branded initiative under a name such as the World Wild Web. This would provide a framework within which conservation tourism could operate more effectively; place increasing scrutiny on the conservation outcomes of stewardship schemes; enhance the effectiveness of local conservation initiatives in rapidly developing nations; and provide an opportunity to gain large-scale multilateral funding as one component of global adaptation to anthropogenic climate change.

\section{ACKNOWLEDGMENTS}

My thanks for invaluable discussions with: Les Carlisle of Conservation Corporation Africa; Chris Roche and others of Wilderness Safaris; Claudia Ollenburg in relation to conservation on private agricultural landholdings; and Graeme Worboys and other members of the IUCN World Commission on Protected Areas, Australia's Biological Diversity Advisory Committee, and various World Heritage Scientific Advisory Committees.

\section{REFERENCES}

Abakerli, S. 2001. A critique of development and conservation policies in environmentally sensitive regions in Brazil. Geoforum 32:551-565

Asquith, N.M., M.T. Vargas, and S. Wunder. 2008. Ecological Economics 65(4): 675-684

Australian Wildlife Conservancy. 2008. http://www.awc.org.au/. Cited 23 Jun 2008.

Bayliss, K., S. Peplow, G. Rausser, and L. Simon. 2008. Agrienvironmental policies in the EU and United States: a comparison. Ecological Economics 65(4):753-764

Beier, P., and R.F. Noss. 1998. Do habitat corridors provide connectivity? Conservation Biology 12: 1251-1252

Bennett, A.F. 1999. Linkages in the landscape: the role of corridors and connectivity in wildlife conservation. IUCN, $254 \mathrm{pp}$.

Berentsen, P.B.M., A. Hendriksen, W.J.M. Heijman, and H.A. van Vlokhoven. 2007. Costs and benefits of on-farm nature conservation. Ecological Economics 62(3-4):571-579

Brooks, T.M., R.A. Mittermeier, G.A.B. da Fonseca, J. Gerlach, M. Hoffman, J.F. Lamoreux, C.G. Mittermeier, J.D. Pilgrim, A.S.L. Rodrigues. 2006. Global biodiversity conservation priorities. Science 313:58-61

Buckley, R.C. 2003. Case studies in ecotourism. CAB International, Oxford.

Buckley, R.C. 2006. Adventure tourism. CAB International, Oxford.

Buckley, R.C. 2008. Ecotourism: principles and practices. $\mathrm{CAB}$ International, Oxford (in press).

Claassen, R., A. Cattaneo, and R. Johansson. 2008. Cost-effective design of agri-environmental payment programs: US experience in theory and practice. Ecological Economics 65(4):737-752

Conservation Corporation Africa. 2008. Reawaken Your Soul. http:// www.ccafrica.com/ Cited 3 Jun 2008

Conservation Finance Alliance. 2003. The conservation finance guide. IUCN, Gland, Switzerland.

Conservation International. 2008. Discover Learn Explore Act Give. http://www.conservation.org Cited 23 Jun 2008

Cooper, J.C., and G. Signorello. 2008. Farmer premiums for the voluntary adoption of conservation plans. Journal of Environmental Planning and Management 51(1):1-14

Cowell, S., and C. Williams. 2006. Conservation through buyer-diversity: a key role for not-for-profit land-holding organizations in Australia. Ecological Management and Restoration 7(1):5-20

Crooks, K.R., and M. Sanjayan (Eds). 2006. Connectivity conservation.
Cambridge, University Press

Damschen, E.I., N.M. Haddad, J.L. Orrock, J.J.Tewksbury, and D.J. Levey. 2006. Corridors increase plant species richness at large scales. Science 313: 1284-1286

de Nooij, R.J.W., R.S.E.W. Leuven, H.J.R. Lenders, T.E.P.A. Lam, and S. Pieters. 2008. Relating the ecological and legal frameworks for nature conservation in Europe. Journal of International Wildlife Law and Policy 11(1):63-95

Dobbs, T.L., and J. Pretty. 2008. Case study of agri-environmental payments: the United Kingdom. Ecological Economics 65(4):765-775

Donald, P.F., and A.D. Evans. 2006. Habitat connectivity and matrix restoration: the wider implications of agri-environ schemes. Journal of Applied Ecology 43(2):209-218

Drechsler, M., K. Johst, C. Ohl, and F. Watzold. 2007. Designing costeffective payments for conservation measures to generate spatiotemporal habitat heterogeneity. Conservation Biology 21(6):1475-1486

Engel, S., and C. Palmer. 2008. Payments for environmental services as an alternative to logging under weak property rights: the case of Indonesia. Ecological Economics 65(4):799-809

Engel, S., S. Pagiola, and S. Wunder. 2008. Designing payments for environmental services in theory and practice: an overview of the issues. Ecological Economics 65(4):663-674

Ferraro, P.J. 2008. Asymmetric information and contract design for payments for environmental services. Ecological Economics 65(4):810821

Ferraro, P.J., and A. Kiss. 2002. Direct payments to conserve biodiversity. Science 298: 1718-1719

Fischer, J., and D.B. Lindenmayer. 2007. Landscape modification and habitat fragmentation: a synthesis. Global Ecology and Biography 16: 265-280

Gardner, T.A., T.I.M. Caro, E.M. Fitzherbert, T. Banda, and P. Lalbhai. 2007. Conservation value of multiple-use areas in East Africa. Conservation Biology 21(6):1516-1525

Goldman, R.L., B.H. Thompson, and G.C. Daily. 2007. Institutional incentives for managing the landscape: inducing cooperation for the production of ecosystem services. Ecological Economics 64(2):333343

Gulati, S., and J. Vercammen. 2006. Time inconsistent resource conservation contracts. Journal of Environmental Economics and Management 52:454-468

Hallwood, P. 2007. Contractual difficulties in environmental management: the case of wetland mitigation banking. Ecological Economics 63(23):446-451

Herzon, I., and M. Mikk. 2007. Farmers' perceptions of biodiversity and their willingness to enhance it through agri-environment schemes: a comparative study from Estonia and Finland. Nature Conservation 15:10-25

Holzkamper, A., and R. Seppelt. 2007. Evaluating cost-effectiveness of conservation management actions in an agricultural landscape on a regional scale. Biological Conservation 136:117-127

House, A.P.N., N.D. MacLeod, B. Cullen, A.M. Whitbread, S.D. Brown, and J.G. McIvor. 2008. Integrating production and natural resource management on mixed farms in eastern Australia: the cost of conservation in agricultural landscapes. Agriculture, Ecosystems and Environment 127:153-165

IUCN. 2008. World Conservation Union. http://www.iucn.org. Cited 23 Jun 2008

Iverson, V., B. Chhetry, P. Francis, M. Gurung, G. Kafle, A. Pain, and J. Seeley. 2006. High value forests, hidden economies and elite capture: evidence from forest user groups in Nepal's Terai. Ecological Economics 58(1):93-107

Johns, D. 2007. Like it or not, politics is the solution. Conservation Biology 21(2): 287-288

Kareieva, P., M. Marvier. 2003. Conserving biodiversity coldspots: recent calls to direct conservation funding to the world biodiversity hotspots may be bad investment advice. American Scientist 91:344-352

Kleijn, D., and W.J. Sutherland. 2003. How effective are European agri-environment schemes in conserving and promoting biodiversity? Journal of Applied Ecology 40: 947-969

Knop, E., D. Kleijn, F. Herzog, and B. Schmid. 2006. Effectiveness of the Swiss agri-environment scheme in promoting biodiversity. Journal of Applied Ecology 43(1):120-127

Kosoy, N., M. Martinez-Tuna, R. Muradian, and J. Martinez-Alier. 2007. Payments for environmental services in watersheds: insights from a comparative study of three cases in Central America. Ecological Economics 61(2-3): 446-455

Kruger, 0. 2005. The role of ecotourism in conservation: panacea or Pandora's box? Biodiversity and Conservation 14(3):579-600 
Langholz, J.A., J.P. Lassoie, D. Lee, and D. Chapman. 2000. Economic considerations of privately owned parks. Ecological Economics 33: 173-183

Langpap, C. 2006. Conservation of endangered species: can incentives work for private landowners? Ecological Economics 57(4):558-572

Lees, A.C., C.A. Peres. 2008. Conservation value of remnant riparian forest corridors of varying quality for Amazonian birds and mammals. Conservation Biology 22(2):439-449

Leroux, S.J., and F.K.A. Schmiegelow. 2007. Biodiversity concordance and the importance of endemism. Conservation Biology 21:274-277

Lindsey, P.A., R.R. Alexander, J.T. du Toit, and M.G.L. Mills. 2005. The potential contribution of ecotourism to African Wild Dog Lycaon pictus conservation in South Africa. Biological Conservation 123:339348

Lockwood, M., G. Worboys, and A. Kothari. 2006. Managing Protected Areas: a Global Guide. Earthscan, London.

McDonald R.I., C. Yuan-Farrell, C. Fievet, M. Moeller, P. Kareiva, D. Foster, T. Gragson, A. Kinzig, L. Kuby, and C. Redman. 2007. Estimating the effect of protected lands on the development and conservation of their surroundings. Conservation Biology 21(6):15261536

Mackey, B., H. Keith, and S. Berry. 2008. Green carbon. Australian National University, Canberra (in press).

Millennium Ecosystem Assessment (MEA). 2005. Ecosystems and human well-being: policy responses: findings of the responses working group of the millennium ecosystem assessment. Island Press, Washington DC.

Munoz-Pina, C., A. Guevara, J.M. Torres, and J. Brana. 2008. Paying for the hydrological services of Mexico's forests: analysis, negotiations and results. Ecological Economics 65(4): 725-736

Murdoch, W., S. Polasky, K.E. Wilson, H.P. Possingham, P. Kareiva, and R. Shaw. 2007. Maximizing return on investment in conservation. Biological Conservation 139(3-4):375-388

Murphy, D.D., and B.R. Noon. 2007. The role of scientists in conservation planning on private lands. Conservation Biology 21:25-28

Myers, N., R.A. Mittermeier, C.G. Mittermeier, G.A.B. da Fonseca, J. Kent. 2000. Biodiversity hotspots for conservation priorities. Nature 403:853-858

Natural Habitat Adventures. 2008. The Nature People. http://www. nathab.com. Cited 23 Jun 2008.

New South Wales Department of Environment and Climate Change (NSWDECC). 2008. Alps to Atherton Initiative. http://www. environment.nsw.gov.au/a2a/index.htm. Cited 23 Jun 2008

Pagiola, S. 2008. Payments for environmental services in Costa Rica. Ecological Economics 65(4): 712-724

Pagiola, S., E. Ramirez, J. Gobbi, C. de Haan, M. Ibrahim, E. Murgueitio, and J.P. Ruiz. 2007. Paying for the environmental services of silvopastoral practices in Nicaragua. Ecological Economics 64:374-385

Parkhurst, G.M., and J.F. Shogren. 2007. Spatial incentives to coordinate contiguous habitat. Ecological Economics 64(2):344-355

Pressey, R.L. 2007. Conservation planning for a changing climate. In: Protected areas: buffering nature against climate change. WWF, Gland, pp. 90-94

Pressey, R.L., M. Cabeza, W.E. Watts, R.M. Cowling, and K.A. Wilson. 2007. Conservation planning in a changing world. Trends in Ecology and Evaluation 22: 583-592

Puppim de Oliveira, J.A. 2005. Tourism as a force for establishing protected areas: the case of Bahia, Brazil. Journal of Sustainable Tourism 13(1):24-49

Rissman, A.R., L. Lozier, T. Comendant, P. Kareiva, J.M. Kiesecker, M.R. Shaw, and A.M. Merenlender. 2007. Conservation easements: biodiversity protection and private use. Conservation Biology 21(3):709718

Rondinini, C., F. Chiozza, and L. Boitani. 2006. High human density in the irreplaceable sites for African vertebrates conservation. Biological Conservation 133(3):358-363

Rouget, M., R.M. Cowling, A.T. Lombard, A.T. Knight, G.H. Kerley. 2006. Designing large-scale conservation corridors for pattern and process. Conservation Biology 20: 549-561

Salafsky N, R. Margoluis, K.H. Redford, J.G. Robinson. 2002. Improving the practice of conservation: A conceptual framework and research agenda for conservation science. Conservation Biology 16:1469-1479

Sanchez-Azofeifa, G.A., A. Pfaff, J.A. Robalino, and J.P. Boomhower. 2007. Costa Rica's payment for environmental services program: intention, implementation and impact. Conservation Biology 21(5):11651173

Save the Rhino Trust. 2008. Save the Rhino International. http://www. savetherhino.org/etargetsrinm/site/1/default.aspx. Cited 23 Jun 2008.
Shepherd, B., and J. Whittington. 2006. Response of wolves to corridor restoration and human use management. Ecology and Society 11(2):1

Shone, B.M., and J.L. Caviglia-Harris. 2006. Quantifying and comparing the value of non-timber forest products in the Amazon. Ecological Economics 58(2):249-267

Shultis, J.D., and P.A. Way. 2006. Changing conceptions of protected areas and conservation: linking conservation, ecological integrity and tourism management. Journal of Sustainable Tourism 14(3):223-237

Sierra, R., and E. Russman. 2006. On the efficiency of environmental service payments: a forest conservation assessment in the Osa Peninsula, Costa Rica. Ecological Economics 59(1):131-141

Spiteri, A., and S.K. Nepal. 2005. Incentive-based conservation programs in developing countries: a review of some key issues and suggestions for improvements. Environmental Management 37(1):1-14

Straka, T.J., M.A. Kilgore, M.G. Jacobson, J.L. Greene, and S.E. Daniels. 2007. Influence of financial incentive programs in sustaining wildlife values. Human Dimensions of Wildlife 12(3):197-199

Sutherland, W.J. 2000. The conservation handbook: Techniques in research, management and policy. Blackwell, Oxford

Svoronou, E., and A. Holden. 2005. Ecotourism as a tool for nature conservation: the role of WWF Greece in the Dadia-Lefkimi-Soufli Reserve in Greece. Journal of Sustainable Tourism 13:456-467

Terborgh, J. 1999. Requiem for nature. Shearwater, Washington DC.

The Nature Conservancy. 2008. Conservation science. http://www.nature. org/tncscience/docs. Cited 23 Jun 2008

Tisdell, C., C. Wilson, and H.S. Nantha. 2005. Policies for saving a rare Australian glider: economics and ecology. Biological Conservation $123: 237-248$

Tourism Industry Carbon Offset Service. 2008. Welcome to TICOS.

www.ticos.co.uk Cited 22 Aug 2008.

Turpie, J.K., C. Marais, and J.N. Blignaut. 2008. The working for water programme: evolution of a payments for ecosystem services mechanism that addresses both poverty and ecosystem service delivery in South Africa. Ecological Economics 65(4):788-798

UNEP. 2007. User's Manual on the CBD Guidelines on Biodiversity and Tourism Development 122pp.

Van der Horst, D. 2007. Assessing the efficiency gains of improved spatial targeting of policy interventions; the example of an agrienvironmental scheme. Journal of Environmental Management 85(4):1076-1087

Walker S, R. Price, and R.T. Theo Stephens. 2008. An index of risk as a measure of biodiversity conservation achieved through land reform. Conservation Biology 22(1):48-59

Wallace, G.N., D.M. Theobald, T. Ernst, and K. King. 2008. Assessing the ecological and social benefits of private land conservation in Colorado. Conservation Biology 22(2):284-296

Watson, A., and W. Borrie. 2003. Applying public-purpose marketing in the USA to protect relationships with public lands. In: Buckley R, Pickering C, Weaver D (Eds) Nature-based tourism, environment and land management. CAB International, Oxford.

Wiegand, T., E. Revilla, and K.A. Moloney. 2005. Effects of habitat loss and fragmentation on population dynamics. Conservation Biology 19:108-121

Wilderness Safaris. 2008. Our Journeys Change People's Lives. http:// www.wilderness-safaris.com/. Cited 3 Jun 2008

Wildlands Project. 2008. Reconnect Restore Rewild http://www.twp.org. Cited 23 Jun 2008

Wilkie, D., G. Morelli, J. Demmer, M. Starkey, P. Telfer, and M. Steil. 2006. Parks and people: Assessing the human welfare effects of establishing protected areas for biodiversity conservation. Conservation Biology 20: 247-249

Wilson, R.G., H. Marsh, and J. Winter. 2007. Importance of canopy connectivity for home range and movements of the rainforest arboreal ringtail possum. Wildlife Research 34(3):177-184

Worldwide Fund for Nature. 2008. For a living planet. http://www.panda. org. Cited 23 Jun 2008

Wunder, S., S. Engel, and S. Pagiola. 2008. Taking stock: a comparative analysis of payments for environmental services programs in developed and developing countries. Ecological Economics 65(4): $834-852$

Wunder, S. 2007. The efficiency of payments for environmental services in tropical conservation. Conservation Biology 21(1):48-58

Wunscher, T., S. Engel, and S. Wunder. 2008. Spatial targeting of payments for environmental services: a tool for boosting conservation benefits. Ecological Economics 65(4):822-833

Zabel, A., and K. Holm-Muller. 2008. Conservation performance payments for carnivore conservation in Sweden. Conservation Biology $22(2): 247-251$ 